\title{
Pioglitazone as a modulator of the chemoresistance of renal cell adenocarcinoma to methotrexate
}

\author{
IWONA PIĄTKOWSKA-CHMIEL, MONIKA GAWROŃSKA-GRZYWACZ, DOROTA NATORSKA-CHOMICKA, \\ MARIOLA HERBET, MARCIN SYSA, MAGDALENA IWAN, AGNIESZKA KORGA and JAROSŁAW DUDKA
}

\author{
Department of Toxicology, Faculty of Pharmacy and Medical Analytics Division, \\ Medical University of Lublin, PL 20-090 Lublin, Poland
}

Received June 13, 2019; Accepted December 11, 2019

DOI: $10.3892 /$ or.2020.7482

\begin{abstract}
Kidney cancer is one of the most lethal urological malignancies associated with a high risk of mortality. Recent studies have shown that several antidiabetic drugs may limit the risk of the growth of different types of cancer. Pioglitazone (PIO) belongs to a novel class of antidiabetic drugs called thiazolidinediones (TZDs), which are commonly used in the treatment of type 2 diabetes. This drug has been demonstrated to exert an inhibitory effect on cell growth in colon, prostatic, breast and pancreatic cancer lines. The aim of the present study was to assess the inhibitory effect of PIO on the proliferation of the renal adenocarcinoma cell line 769-P. In addition, the proapoptotic potential of combined treatment with PIO and methotrexate (MTX) was evaluated, as well as the impact of the above drugs on the cell cycle of the 769-P cells. The present study showed that PIO efficaciously inhibited the proliferation and viability of renal cancer cells, and it induced sub-G1 cell cycle arrest and a decrease in the number of cells in the G2 phase, which indicated cytotoxic activity. PIO also exhibited proapoptotic properties at the lowest dose applied $(10 \mu \mathrm{M})$. Furthermore, combined therapy with PIO and MTX increased the sensitivity of tumor cells to MTX while at the same time this combined therapy did not exhibit a cytotoxic effect to normal kidney cells. In renal adenocarcinoma cells, the combination of the above cytostatic agent at the lowest dose administered (MTX, $5 \mu \mathrm{M}$ ) with the peroxisome proliferator-activated receptor $\gamma$ agonist PIO exhibited better efficacy in triggering the process of apoptosis than that displayed by MTX alone.
\end{abstract}

Correspondence to: Dr Iwona Piątkowska-Chmiel, Department of Toxicology, Faculty of Pharmacy and Medical Analytics Division, Medical University of Lublin, 8b Jaczewskiego Street, PL 20-090 Lublin, Poland

E-mail: iwona.piatkowska-chmiel@umlub.pl

Key words: pioglitazone, methotrexate, renal cell adenocarcinoma, cell cycle, apoptosis

\section{Introduction}

Cancer is one of the most common causes of death and a major health concern worldwide (1). However, effective treatment of patients remains a real and serious challenge in oncology. Conventional therapeutic methods, including chemotherapy, radiotherapy and surgery, often are not sufficiently effective or have a high risk of adverse effects for patients $(1,2)$. An increasingly noted therapeutic issue is the development of tumor cell resistance to the applied treatment, which can be associated with poor vascularization of the tumor, silencing of the apoptotic pathway and reinforcement of the DNA repair mechanism in cells. It is estimated that $\sim 40 \%$ of tumors are resistant to conventional chemotherapy, which significantly increases the risk of relapse $(3,4)$. Renal cell carcinoma (RCC), also called renal adenocarcinoma, remains one of the most lethal urological malignancies in the world, and is associated with a high resistance to conventional therapy. Adenocarcinomas represent $>90 \%$ of kidney carcinomas. The main method of treatment is surgical resection, which is effective only in $\sim 70 \%$ of cases with early-stage and localized RCC (5). Over the last decade, a constantly increasing incidence of RCC has been observed in Eastern and Western European countries, including Poland (1,6-9). The number of reports focusing on factors that can promote the development of kidney cancer such as smoking, obesity, diabetes and hypertension, continues to grow (2). Recent epidemiologic studies have shown that patients with diabetes (mainly type 2) may be predisposed to develop not only nephropathy but also several malignancies, including kidney cancer, when compared with the general population (9-17).

Considering the increasing incidence of kidney cancer and the limitations of current therapy, the main objective of contemporary medicine is the identification of novel therapeutic agents that will be able to increase the sensitivity of tumor cells to cytostatic drugs while reducing their cytotoxic effect on normal cells. One of the suggested strategies is the combination of anticancer drugs with other non-cytostatic therapeutic agents. Numerous preclinical, epidemiological and clinical studies have shown that antidiabetic drugs such as metformin or pioglitazone (PIO) may have anticancer activity (18-22). Recently, this area has gained increased attention due to the growing global diabetes epidemic as well as current findings 
that suggest that certain antidiabetic drugs may reduce the risk of cancer and could be considered in cancer therapy. Thiazolidinediones (TZDs), which act as ligands to nuclear peroxisome proliferator-activated receptor (PPAR) $\gamma$, represent an essential group of antidiabetic drugs that could be used in cancer treatment. This concept is supported by the finding that PPAR $\gamma$ is involved in cell proliferation, and PPAR $\gamma$ expression levels vary from normal to tumor tissues (23). Previous studies have shown that this receptor is highly expressed also in human renal cell adenocarcinoma $(21,24,25)$. Moreover, previous studies confirmed that PPAR $\gamma$ is detected in various human cancer cells, including colon (26), prostate (27), bladder (28), lung (29) and breast (24). The results of clinical trials indicate the efficacy of TZDs as monotherapy in prostate cancer and glioma as well as colon, lung and breast cancer $(24,27,29)$. TZDs in combination with other therapies could enhance antitumor effects in melanoma, thyroid cancer and soft tissue sarcoma (23).

PIO is an oral hypoglycaemic agent of TZDs used for the management of type 2 diabetes. Its mechanism of action is associated with the activation of the nuclear receptor PPAR $\gamma(19,22)$. PPAR $\gamma$ agonists are known to exert a nephroprotective effect in diabetic patients $(30,31)$. However, Yuan et al (21) demonstrated that PIO could also effectively inhibit the proliferation and promote the apoptosis of human RCC cell lines. Therefore, TZDs may also have a significant inhibitory effect on the progression of kidney cancer. Methotrexate (MTX) is one of the most widely used anticancer drugs. It is used alone or in combination with other cytostatic agents to treat certain types of cancer such as breast, skin, head and neck or lung cancer $(32,33)$. Notably, preclinical and clinical studies have identified antifolate resistance in certain tumor cells, which is a basic obstacle to effective chemotherapy $(34,35)$. Development of cancer cell resistance to MTX is considered to be a multifactorial process due to a defect in drug uptake by the cells and alterations in dihydrofolate reductase (DHF). The above modifications result in a decrease in affinity for MTX, an increase in DHF reductase levels, dysregulation of apoptosis, insufficient MTX polyglutamylation rate and tumor cell DNA repair (36-39). Although MTX is an efficient drug in several types of urological cancer (including bladder cancer) and it is used in first-line chemotherapy regimens for advanced urothelial cancer, the potential beneficial effects of this drug in kidney cancer have not been described thus far (40). Therefore, the aim of our study was to evaluate the efficacy of monotherapy with MTX as well as combined therapy (MTX + PIO) in renal cell adenocarcinoma (769-P) and suggest the potential anticancer activity of PIO.

Several studies have indicated that certain antidiabetic drugs such as metformin or PIO can potentiate the effect of chemotherapeutic agents, including gemcitabine, 5-fluorouracil, arsenic trioxide and cisplatin, or even reverse drug resistance in cancer cells $(37,41-43)$. However, to date, the effects of the combined application of PIO and MTX on renal cell adenocarcinoma have not been described in the scientific literature.

\section{Materials and methods}

Cell culture. The present study was performed on normal green monkey kidney Vero cells (cat. no. CCL-81 ${ }^{\mathrm{TM}}$ ) and human renal cell adenocarcinoma 769-P cells (cat. no. CRL-1933 ${ }^{\mathrm{TM}}$ ), which were obtained from the American Type Culture Collection. The Vero cell line was cultured in Eagle's Minimum Essential Medium (EMEM medium), while the 769-P cell line was cultured in RPMI-1640 medium (containing L-glutamine, sodium pyruvate, $4.5 \mathrm{~g} / 1$ glucose, HEPES and sodium dicarbonate). The cells were cultured in a humidified atmosphere of $5 \% \mathrm{CO}_{2}$ at $37^{\circ} \mathrm{C}$ in a cell incubator and supplemented with $10 \%$ FBS and antibiotics: $100 \mathrm{U} / \mathrm{ml}$ penicillin, $100 \mu \mathrm{g} / \mathrm{ml}$ streptomycin and $2.5 \mu \mathrm{g} / \mathrm{ml}$ amphotericin B which were supplied by PAN Biotech $\mathrm{GmbH}$. Cells were grown in $75-\mathrm{cm}^{2}$ tissue culture flasks (EasYFlasks ${ }^{\mathrm{TM}}$ Nunclon $^{\mathrm{TM}} \Delta$; Nalge Nunc International). Before the experiment, cells were trypsinized (0.25\% trypsin/2.21 mM EDTA) and seeded in 96- or 6-well plates (SPL Life Sciences) at a density of $1 \times 10^{6}$ cells $/ \mathrm{ml}$. The prepared plates were incubated for $24 \mathrm{~h}$ to allow the cells to adhere to the plates. After $24 \mathrm{~h}$ of cell adhesion, drugs pioglitazone (i.e., 10, 25 and $50 \mu \mathrm{M}$ ) and methotrexate (i.e., $5 \mu \mathrm{M}, 10 \mu \mathrm{M}$ ) were added to the cells in increasing concentrations, and incubated for an additional $24 \mathrm{~h}$. Control cells were incubated with the appropriate medium.

Drugs and reagents. The following drugs and reagents were used in the present study: PIO (Bioton S.A.), MTX (EBEWE Pharma GmbH Nfg. KG), MTT (Sigma-Aldrich; Merck KGaA), dimethyl sulfoxide (DMSO; Avantor Performance Materials S.A.), PBS (Mediatech, Inc. Corning Inc.). Rich-component RPMI-1640 medium, FBS and antibiotics (penicillin, streptomycin and amphotericin B) were supplied by PAN Biotech $\mathrm{GmbH}$. Trypsin solution (0.25\% trypsin/2.21 mM EDTA) was obtained from Mediatech, Inc. (Corning Inc.).

Drug preparation and treatment. PIO and MTX were dissolved in DMSO to prepare a primary stock solution $\left(1,000\right.$ and $100 \mu \mathrm{M}$, respectively) and stored at $-20^{\circ} \mathrm{C}$. The final concentrations of PIO $(10,25$ and $50 \mu \mathrm{M})$ and MTX (5 and $10 \mu \mathrm{M}$ ) were subsequently prepared by diluting the primary stock with the corresponding medium for the cell line. The combinations of PIO with MTX were used in the following concentrations: PIO $(10 \mu \mathrm{M})$ with $\operatorname{MTX}(5 \mu \mathrm{M})$; PIO $(25 \mu \mathrm{M})$ with MTX $(5 \mu \mathrm{M})$; PIO $(50 \mu \mathrm{M})$ with MTX $(5 \mu \mathrm{M})$ and PIO $(10 \mu \mathrm{M})$ with MTX $(10 \mu \mathrm{M})$; PIO $(25 \mu \mathrm{M})$ with MTX $(10 \mu \mathrm{M})$; and PIO $(50 \mu \mathrm{M})$ with $\mathrm{MTX}(10 \mu \mathrm{M})$. The final concentration of DMSO did not exceed $0.5 \% \mathrm{v} / \mathrm{v}$ and did not affect cell viability. Each cell line was treated with PIO and/or MTX at the above mentioned concentrations for $24 \mathrm{~h}$.

MTT cell viability assay. MTT assay was performed to investigate cell proliferation and viability according to no. 17 of the Database Service on Alternative Methods to Animal Experimentation (European Centre for the Validation of Alternative Methods; European Union Reference Laboratories; https://ec.europa.eu/jrc/en/eurl/ecvam). Solutions of PIO and MTX were prepared ex tempore and added to the cells in a 96 -well plate always in the same volume (100 $\mu \mathrm{l} / \mathrm{well})$ and incubated for $24 \mathrm{~h}$. Subsequently, $20 \mu \mathrm{l}$ MTT solution $(5 \mathrm{mg} / \mathrm{ml}$ in PBS) was added to the each well and incubated for an additional $3 \mathrm{~h}$ at $37^{\circ} \mathrm{C}$. Next, the formazan crystals were dissolved by adding $100 \mu \mathrm{l}$ DMSO. The absorbance was detected using a microplate reader ELx808IU (BioTek Instruments, Inc.) at 
A

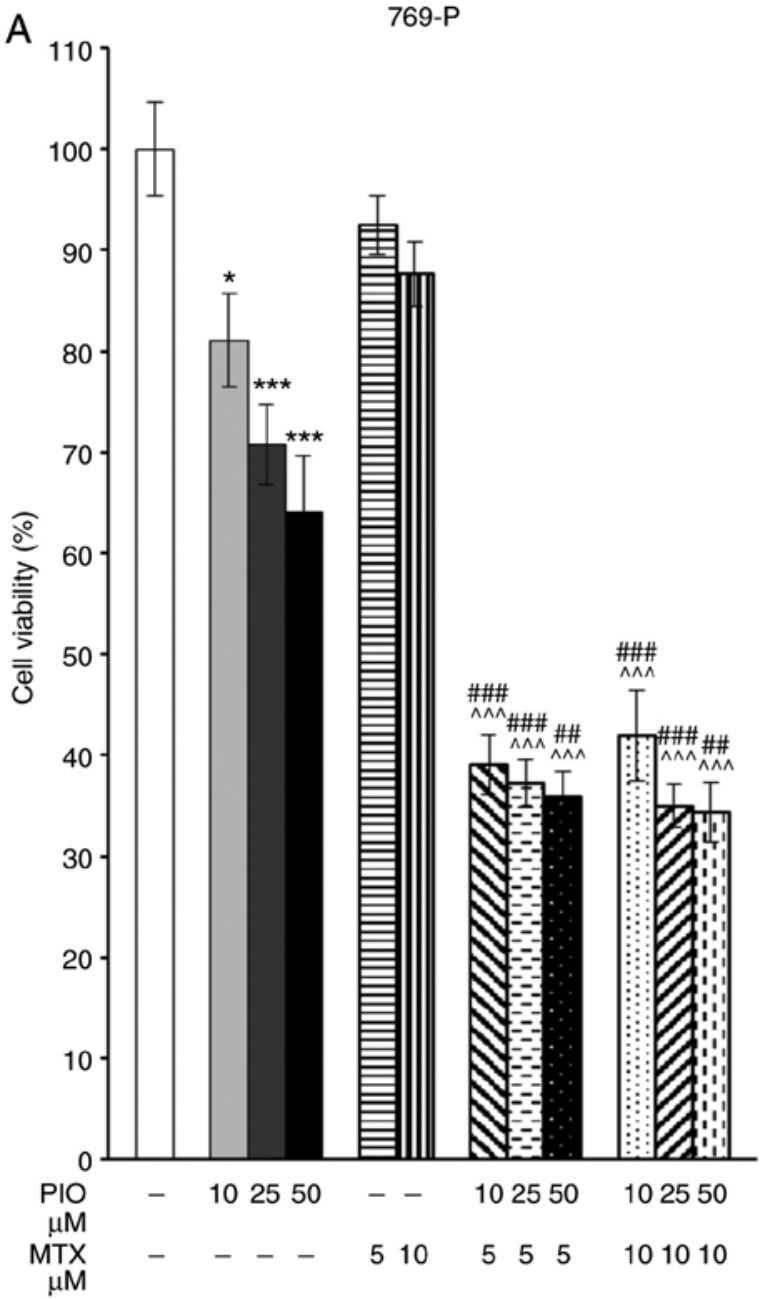

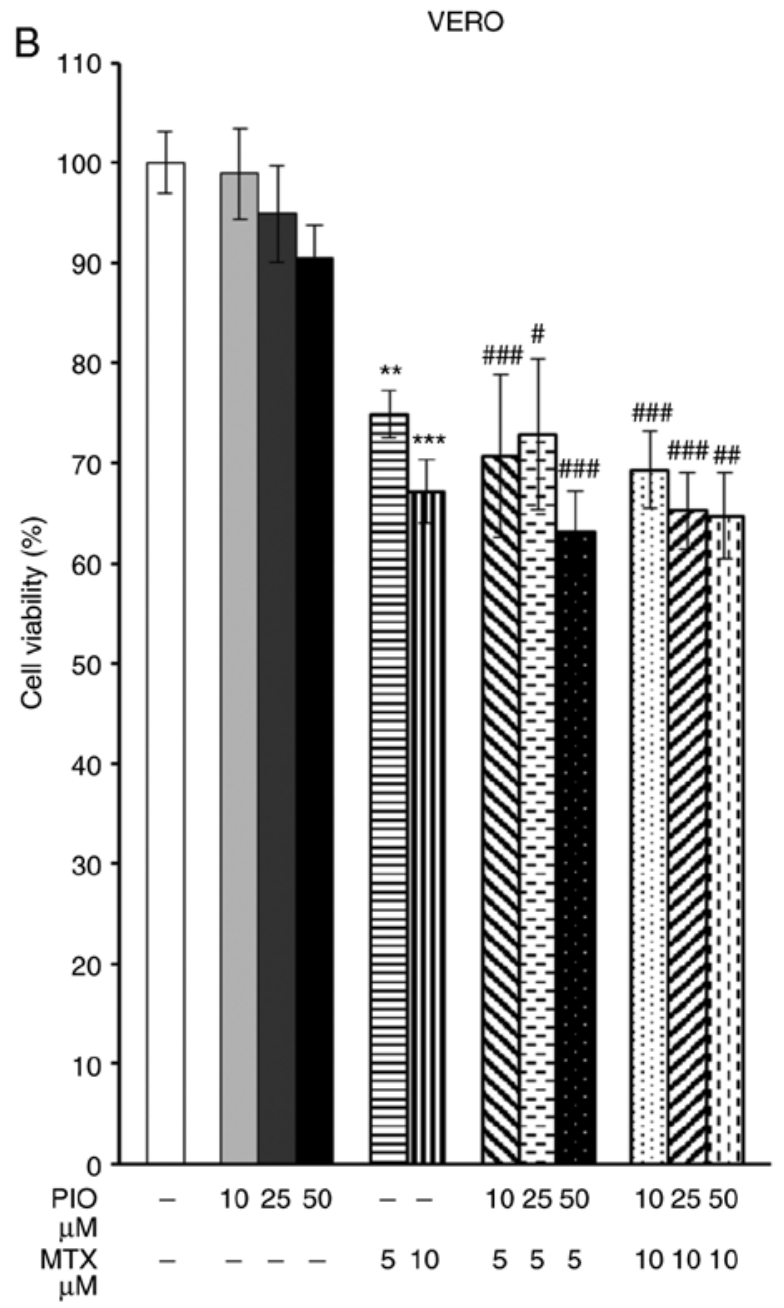

Figure 1. Effect of pioglitazone (PIO) and methotrexate (MTX) on the viability of 769-P cells (A) and normal Vero cell line (B). Cells were treated with different concentrations of drugs for $24 \mathrm{~h}$ and analyzed by the MTT assay. The experiments were repeated 3 times independently and the bars represent the means \pm SEM, $\mathrm{n}=8\left({ }^{*} \mathrm{P}<0.05,{ }^{* *} \mathrm{P}<0.01,{ }^{* * *} \mathrm{P}<0.001\right.$ vs. the control group; ${ }^{\#} \mathrm{P}<0.05,{ }^{\# \#} \mathrm{P}<0.01,{ }^{\# \# \#} \mathrm{P}<0.001$ vs. the PIO group; ${ }^{\wedge \wedge} \mathrm{P}<0.001$ vs. the MTX group).

a wavelength of $550 \mathrm{~nm}$. Cell viability was calculated vs. the untreated cell control, which was set to $100 \%$ viability. The degree of inhibition of growth of the drug-treated cells was expressed as a percentage of the growth of the control cells (without drugs).

Cell cycle analysis. Two-step cell cycle analysis was performed using the NucleoCounter ${ }^{\circledR}$ NC-3000 ${ }^{\mathrm{TM}}$ system (ChemoMetec, Denmark), following the instructions provided by the manufacturer. The analysis is based on measuring the cellular DNA content by DAPI staining, thus allowing the determination of sub-G1/G1, S and G2/M cell cycle phases. The above fluorescent, DNA-selective stain exhibits emission signals proportional to DNA mass. Cell cycle phases are characterized by one set of paired chromosomes per cell (sub-G1/G1) or two sets of paired chromosomes per cell prior to cell division (G2/M). During S phase, characterized by variable amount of DNA, the genetic material of the cell doubles (replication), and simultaneously histone synthesis occurs, which is necessary for the separation of DNA between daughter cells. For cell cycle analysis in the present study, Vero and 769-P cells were seeded at a density of $1 \times 10^{6}$ cells $/ \mathrm{ml}$ in $35-\mathrm{mm} 6$-well plates and treated with various concentrations of PIO and MTX as indicated above for $24 \mathrm{~h}$. After overnight incubation, cells were washed once with PBS, suspended in $250 \mu$ l Solution 10 Lysis Buffer (ChemoMetec) supplemented with $10 \mu \mathrm{l}$ DAPI and incubated for $5 \mathrm{~min}$ at $37^{\circ} \mathrm{C}$. Next $100 \mu \mathrm{l}$ Solution 11 Stabilization Buffer (ChemoMetec) was added. The cell suspension at a volume of $10 \mu l$ was applied to the chambers of NC-Slide $\mathrm{A} 8^{\mathrm{TM}}$ (ChemoMetec) and subjected to cell cycle analysis. The results, in the form of a histogram, represent the percentage of cells in the different phases of the cell cycle (sub-G1/G1, S and G2/M).

Cell apoptosis analysis. Cell apoptosis analysis was conducted using the Annexin V assay for the NucleoCounter ${ }^{\circledR} \mathrm{NC}-3000^{\mathrm{TM}}$ system (ChemoMetec), according to the manufacturer's instructions. This assay is based on the measurement of the translocation of phosphatidylserine to the outer membrane layer (externalization), which indicates apoptosis. In addition to fluorescently labeled Annexin V (Annexin V-CF488A), the cells were also stained with Hoechst 33342 and propidium iodide (PI). Hoechst 33342 stains the total cell population, both living or dead while Annexin V stains apoptotic and necrotic cells. However, as the membrane integrity of these cells is lost, early-stage apoptotic cells can be distinguished 
A

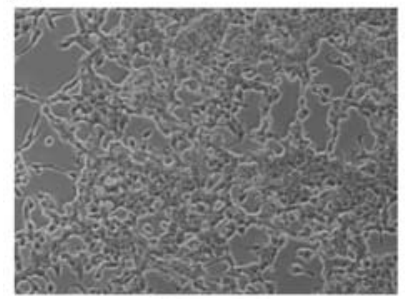

CONTROL

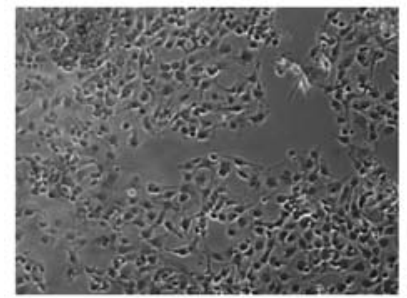

PIO $25 \mu \mathrm{M}$

\begin{tabular}{|l|c|c|c|c|}
\hline Morphology & $\begin{array}{c}\mathrm{CT} \\
\mathrm{RL}\end{array}$ & $\begin{array}{c}\mathrm{PIO} \\
10\end{array}$ & $\begin{array}{c}\mathrm{PIO} \\
25\end{array}$ & $\begin{array}{c}\mathrm{PIO} \\
50\end{array}$ \\
\hline Inhibition of proliferation & - & - & - & ++ \\
\hline Cytoplasm shrinkage & - & + & ++ & +++ \\
\hline $\begin{array}{l}\text { Rounded cells detached } \\
\text { from substrate }\end{array}$ & - & + & ++ & +++ \\
\hline
\end{tabular}

$\mathrm{C}$

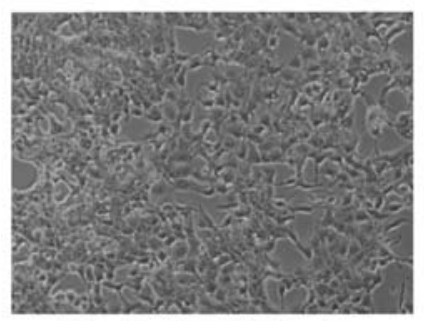

PIO $10 \mu \mathrm{M}+\mathrm{MTX} 5 \mu \mathrm{M}$

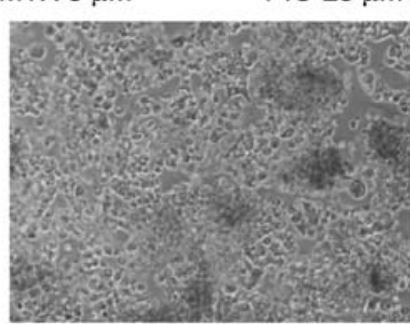

PIO $50 \mu \mathrm{M}+\mathrm{MTX} 5 \mu \mathrm{M}$

\begin{tabular}{|l|c|c|c|}
\hline Morphology & $\begin{array}{c}\text { PO 10 } \\
\text { MTX 5 }\end{array}$ & $\begin{array}{c}\text { PO 25 } \\
\text { MTX 5 }\end{array}$ & $\begin{array}{c}\text { PO 50 } \\
\text { MTX 5 }\end{array}$ \\
\hline Inhibition of proliferation & - & + & + \\
\hline Cytoplasm shrinkage & + & + & ++++ \\
\hline $\begin{array}{l}\text { Rounded cells detached } \\
\text { from substrate }\end{array}$ & - & ++ & ++++ \\
\hline
\end{tabular}

B
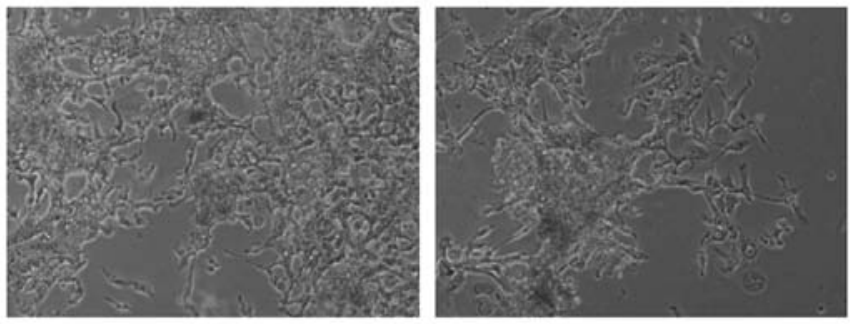

MTX $10 \mu \mathrm{M}$

\begin{tabular}{|l|c|c|}
\hline Morphology & MTX 5 & MTX 10 \\
\hline Inhibition of proliferation & ++ & +++ \\
\hline Cytoplasm shrinkage & ++ & +++ \\
\hline $\begin{array}{l}\text { Rounded cells detached } \\
\text { from substrate }\end{array}$ & + & ++ \\
\hline
\end{tabular}

D

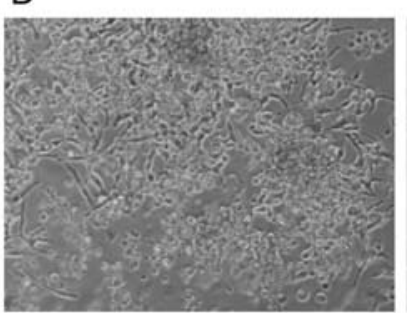

PIO $10 \mu \mathrm{M}+\mathrm{MTX} 10 \mu \mathrm{M}$

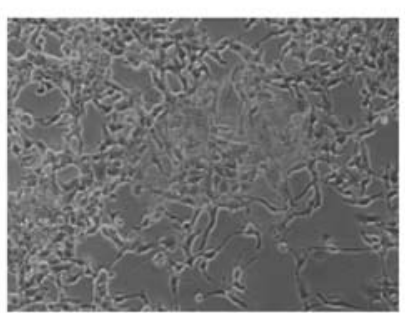

PIO $25 \mu \mathrm{M}+\mathrm{MTX} 10 \mu \mathrm{M}$

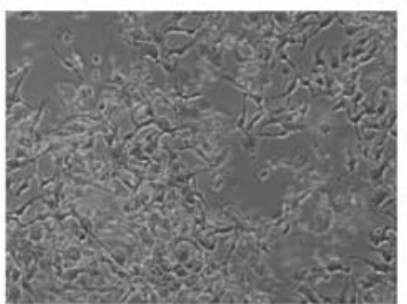

PIO $50 \mu \mathrm{M}+\mathrm{MTX} 10 \mu \mathrm{M}$

\begin{tabular}{|l|c|c|c|}
\hline Morphology & $\begin{array}{c}\text { PIO 10 } \\
\text { MTX 10 }\end{array}$ & $\begin{array}{c}\text { PIO 25 } \\
\text { MTX 10 }\end{array}$ & $\begin{array}{c}\text { PIO 50 } \\
\text { MTX 10 }\end{array}$ \\
\hline Inhibition of proliferation & +++ & ++ & ++ \\
\hline Cytoplasm shrinkage & +++ & ++ & +++ \\
\hline $\begin{array}{l}\text { Rounded cells detached } \\
\text { from substrate }\end{array}$ & +++ & ++ & +++ \\
\hline
\end{tabular}

Figure 2. Effect of a 24-h treatment with (A) pioglitazone (PIO), (B) methotrexate (MTX) and (C and D) their combination on cellular morphology in the 769-P cell line (images and semi-quantifying evaluation of selected features of cells; Nikon Eclipse Ti, Japan; x150 magnification). -, no change compared to Control;,$+ 10 \% ;++, 25 \% ;+++, 50 \%$ and,$++++ 75 \%$.

from late-stage apoptotic and necrotic cells by the use of an impermeant dye such as PI. While Hoechst staining is a necessary step in visualization and differentiation of cells after Annexin V and PI staining, there is no need for plots of Hoechst 33342.

In the present study, Vero and 769-P cells were seeded in 6-well plates and incubated for $24 \mathrm{~h}$ with solutions of PIO and MTX as aforementioned. After treatment, the cells were harvested by centrifugation at $400 \mathrm{x}$ g for $5 \mathrm{~min}$. The supernatant was carefully removed and the cell pellet was gently resuspended in $100 \mu \mathrm{l}$ Annexin V Binding Buffer (Biotium, USA), supplemented with $2 \mu \mathrm{l}$ Annexin V-CF488A and $2 \mu 1$ Hoechst 33342 , and incubated for $15 \mathrm{~min}$ at $37^{\circ} \mathrm{C}$. Subsequently, the stained cells were centrifuged at $400 \mathrm{xg}$ for $5 \mathrm{~min}$ and 
A

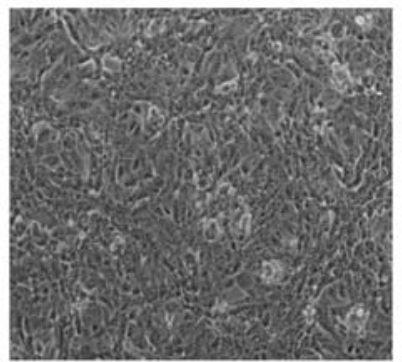

CONTROL

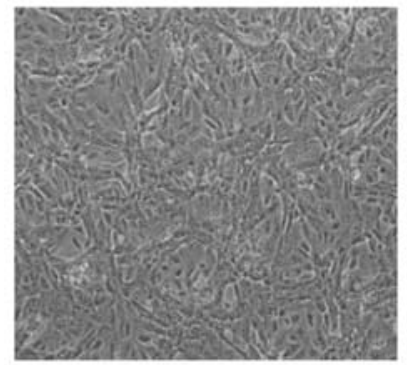

$\mathrm{PIO} 25 \mu \mathrm{M}$

C

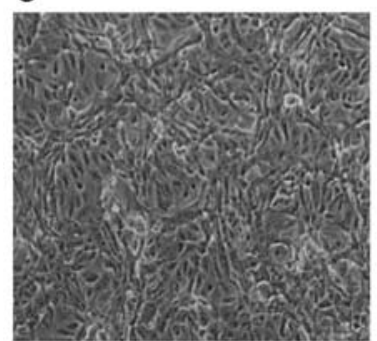

PIO $10 \mu \mathrm{M}+\mathrm{MTX} 5 \mu \mathrm{M}$

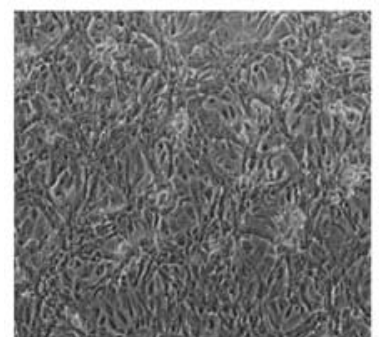

$\mathrm{PIO} 25 \mu \mathrm{M}+\mathrm{MTX} 5 \mu \mathrm{M}$

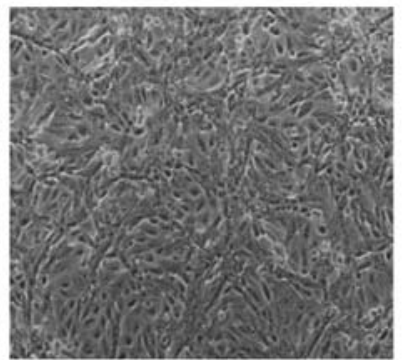

$\mathrm{PIO} 10 \mu \mathrm{M}$

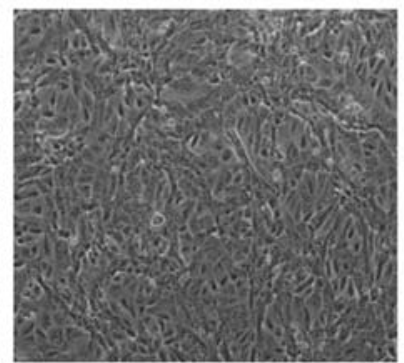

PIO $50 \mu \mathrm{M}$

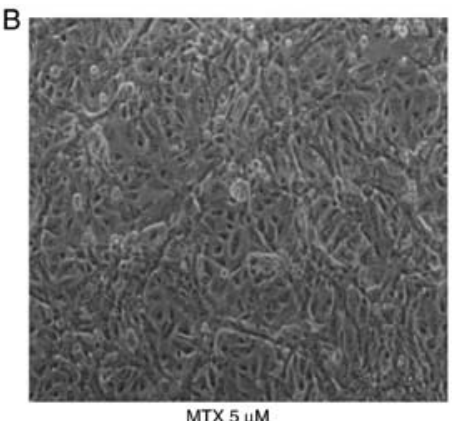

MTX $5 \mu \mathrm{M}$

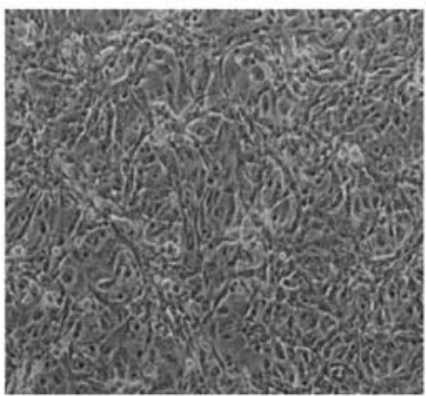

MTX $10 \mu \mathrm{M}$

D

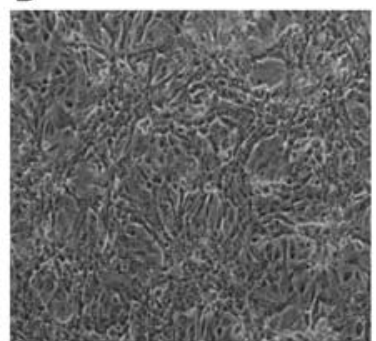

PIO $10 \mu \mathrm{M}+\mathrm{MTX} 10 \mu \mathrm{M}$

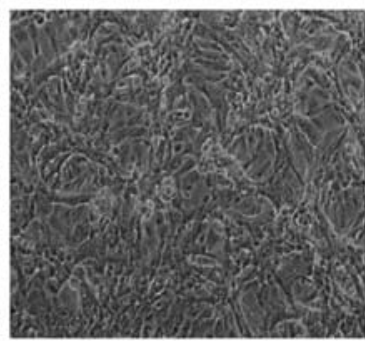

PIO $50 \mu \mathrm{M}+\mathrm{MTX} 5 \mu \mathrm{M}$

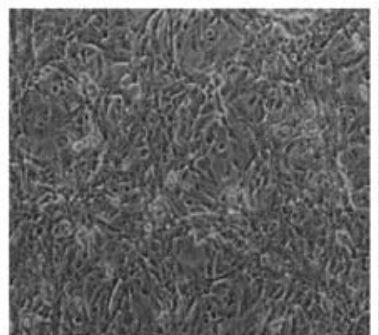

PIO $25 \mu \mathrm{M}+\mathrm{MTX} 10 \mu \mathrm{M}$

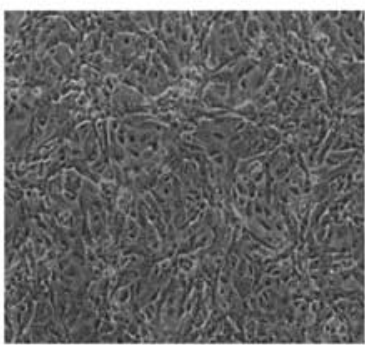

PIO $50 \mu \mathrm{M}+\mathrm{MTX} 10 \mu \mathrm{M}$

Figure 3. Effect of a 24-h treatment with (A) pioglitazone (PIO), (B) methotrexate (MTX) and (C and D) their combination on cellular morphology in the Vero cell line (Nikon Eclipse Ti, Japan; x150 magnification).

resuspended in $100 \mu \mathrm{l}$ Annexin V Binding Buffer with $10 \mu \mathrm{l}$ PI solution. The cell suspension was applied to the chambers of NC-Slide $\mathrm{A} 2^{\mathrm{TM}}$ at a volume of $30 \mu \mathrm{l}$, and subjected to cell apoptosis analysis.

Statistical analysis. The results are expressed as the mean \pm SEM. The statistical comparisons between groups were performed by ANOVA, followed by Bonferroni post hoc test, using Statistica software version 12 (StatSoft, Inc.). $\mathrm{P}<0.05$ was considered to indicate a statistically significant difference.

\section{Results}

Cell viability assay. The inhibitory effects of PIO or/and MTX on the proliferation of renal cell adenocarcinoma cells and the reference normal Vero cell line were estimated and compared by MTT assay. As shown in Fig. 1A, 24-h incubation with PIO led to a significant dose-dependent decrease in cell viability for the kidney cancer cell line 769-P by 21, 29 and $37 \%$, respectively, compared to the viability of the untreated cancer cells. While the viability of Vero cells remained unaffected during the same incubation period (Fig. 1B). The 24-h treatment of cancer cells with MTX $(5$ and $10 \mu \mathrm{M})$ did not cause significant growth inhibition in 769-P cells, contrary to the observations in the normal cell line Vero (Fig. 1A and B, respectively). These results confirm the resistance of renal adenocarcinoma cells to antifolates. After the incubation period with MTX (5 and $10 \mu \mathrm{M})$, the viability of Vero cells was decreased by 25 and 35\%, respectively (Fig. 1B). Furthermore, it was demonstrated that the viability of 769-P cells was 


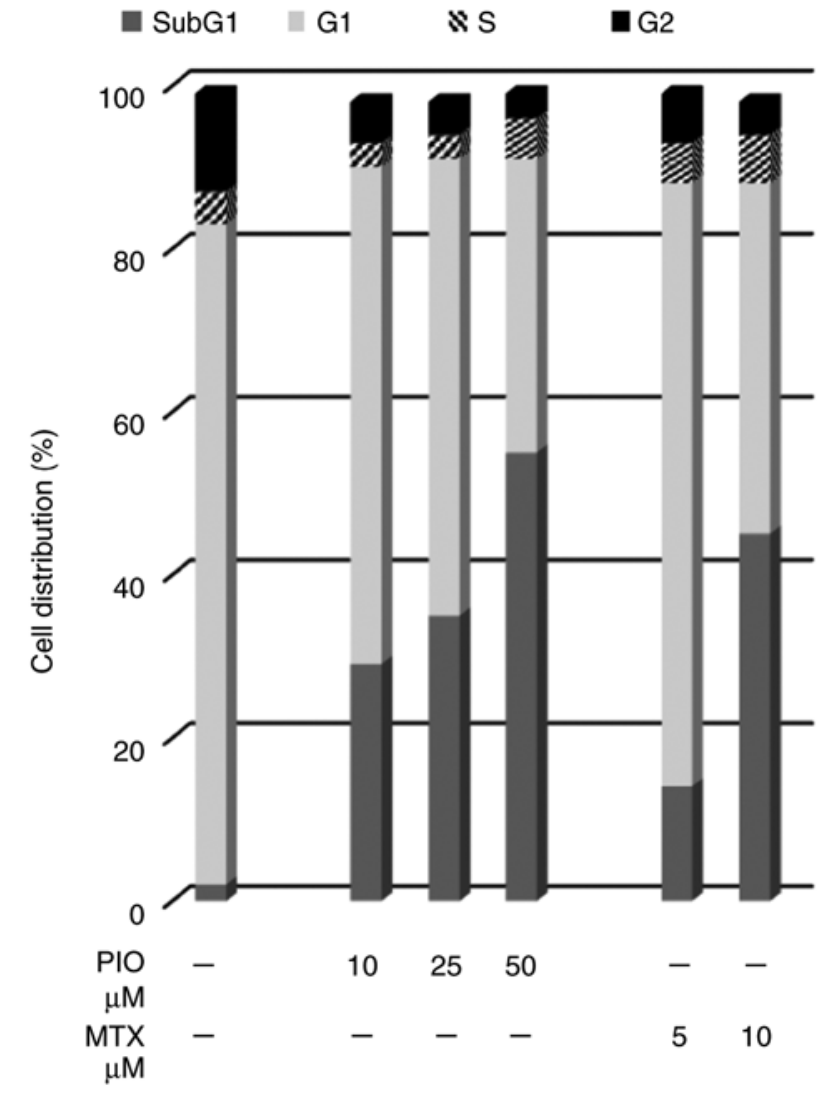

Figure 4. Cell cycle analysis of 769-P cells following a 24-h incubation with different concentrations of pioglitazone (PIO) and methotrexate (MTX). The effect of the drugs, alone and in combination, was investigated by an image analysis using the automated NC-3000 ${ }^{\mathrm{TM}}$ system based on DAPI (4',6-diamidino-2-phenylindole) staining. DAPI is the fluorescent, DNA-selective stain, which exhibits emission signals proportional to DNA mass. This system allows the determination of the percentage of cells in the different cell cycle phases (sub-G1/G1, S and G2/M)

significantly decreased after exposure to the combination of MTX (5 and $10 \mu \mathrm{M})$ and PIO (10, 25 and $50 \mu \mathrm{M})$. The cell viability of the cancer cells was reduced by $40 \%$ within 24 -h after the administration of both drugs. MTX (5 or $10 \mu \mathrm{M})$ in combination with various concentrations of PIO significantly decreased the viability of 769-P cells when compared with the effects of both drugs applied alone. Of note, the increase in MTX dose to $10 \mu \mathrm{M}$ in the combination therapy did not increase the level of cytotoxicity against 769-P cells. Although each combination of PIO and MTX significantly reduced the viability of tumor cells, the cytotoxicity towards normal Vero cells was not enhanced in comparison with that observed when MTX was applied alone at both doses (5 and $10 \mu \mathrm{M})$, as indicated in Fig. 1. However, a significant decrease in Vero cell growth was observed after combined therapy with PIO and MTX compared with that of PIO-treated cells (Fig. 1B). The most beneficial effect in the clinical setting appears to be the combination of low doses of PIO $(10 \mu \mathrm{M})$ and MTX $(5 \mu \mathrm{M})$ in terms of viability of cancer cells as well as the low risk of cytotoxicity towards normal cells.

Microscopic analysis of cells after treatment. For evaluation of the cell morphology, a phase-contrast microscope (Nikon Eclipse Ti; Nikon Corp.) at x150 magnification was used. 769-P and Vero cells grew as a monolayer with typical epithelioid cobblestone morphology (Figs. 2A-D and 3A-D). After a 24-h incubation period of Vero cells with PIO or MTX alone or both drugs together at the aforementioned concentrations, no changes were observed in the morphology of this cell line. However, in the 769-P cell line, adverse changes in general morphology and a reduction in cell culture density were observed due to PIO application in a dose-dependent manner. The occurrence of irregularly shaped cells resulting from shrinkage of the cytoplasm and inhibition of contact growth was observed with the highest PIO concentrations (25 and $50 \mu \mathrm{M}$ ). The cells treated with the highest doses acquired a round shape. This modification of cell morphology is probably due to the partial loss of plasma membrane attachment. These features are characteristic of the earliest phases of the apoptotic process. A 24-h incubation period with MTX resulted in only negligible morphological changes in the 769-P cells. The combination of PIO and MTX led to major changes in the morphology of the tumor cells. The cells acquired a round shape. In the microscopic image, the following characteristic adverse changes were observed: Nuclear blebbing, fragmentation and chromatin condensation, which resulted in the formation of micronuclei and disintegration of the cells. The above changes were most obvious at the highest concentration of PIO.

Cell cycle analysis. As demonstrated in Fig. 4, compared with that of the control, a 24-h treatment with PIO increased the population of 769-P cells in the sub-G1 phase from 2 to a maximum of $55 \%$ in a dose-dependent manner. The G1 phase begins after mitosis and is characterized by intense anabolic processes leading to an increase in the number of cell organelles and the cell mass necessary before replication. During the sub-G1 (G0, sub-G0) phase, cells are deprived of replication, and is characterized by low DNA levels (e.g. apoptotic cells and bodies) (44). Similarly, the administration of MTX at a concentration of $10 \mu \mathrm{M}$ to the tumor cell line resulted in sub-G1 cell cycle arrest. The number of 769-P cells in this stage of the cell cycle increased to $45 \%$ vs. $2 \%$ in the control group. In addition, the percentage of cells in the G2 phase was decreased by 2- to 4-fold after the application of PIO and MTX at all the doses used (Fig. 4). Combination of PIO (25 $\mu \mathrm{M})$ with MTX $(5 \mu \mathrm{M})$ interfered with the renal cell adenocarcinoma cell cycle most markedly, causing an increase in the percentage of sub-G1 cell distribution by an additional $43 \%$ compared with that of the MTX group and by $22 \%$ vs. the PIO group, while cell accumulation in the $\mathrm{S}$ fraction decreased by 2-fold (Fig. 6). Incubation of 769-P cells with PIO and MTX, both at a concentration of $10 \mu \mathrm{M}$, led to a smaller increase in sub-G1 cell accumulation (to $33 \%$ ) and a decrease by half of the cell population in the G2 phase (Fig. 6).

Cell apoptosis assay. By conjugating a fluorescent label to Annexin V, it is possible to identify and quantify apoptotic cells. However, Annexin V is a cellular protein that binds also to necrotic cells but with minor affinity. In addition, early apoptotic cells exclude PI, while late-stage apoptotic and necrotic cells stain positively for this dye. Therefore, the quantification of early apoptotic cells is based on Annexin V binding and PI exclusion. Annexin V and PI double staining clearly showed that 
A
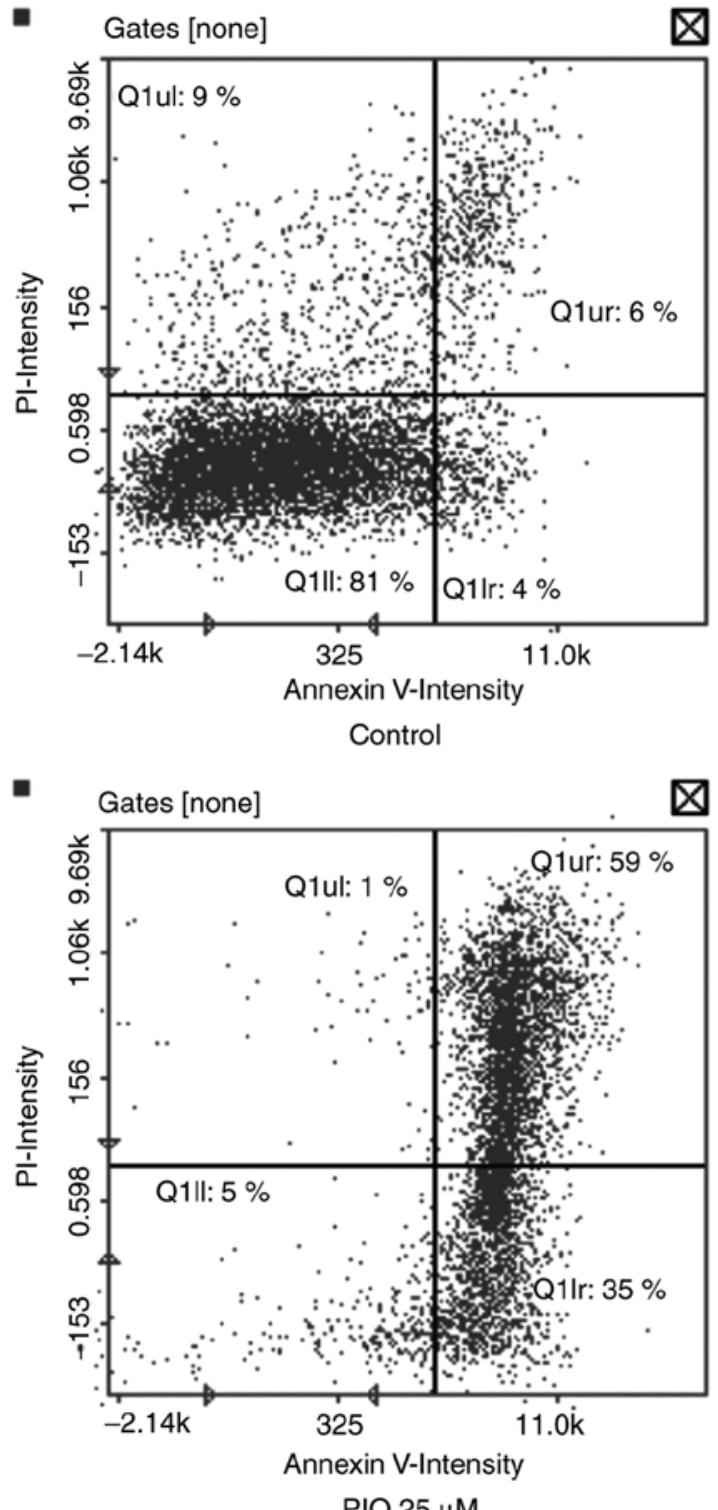

$\mathrm{PIO} 25 \mu \mathrm{M}$

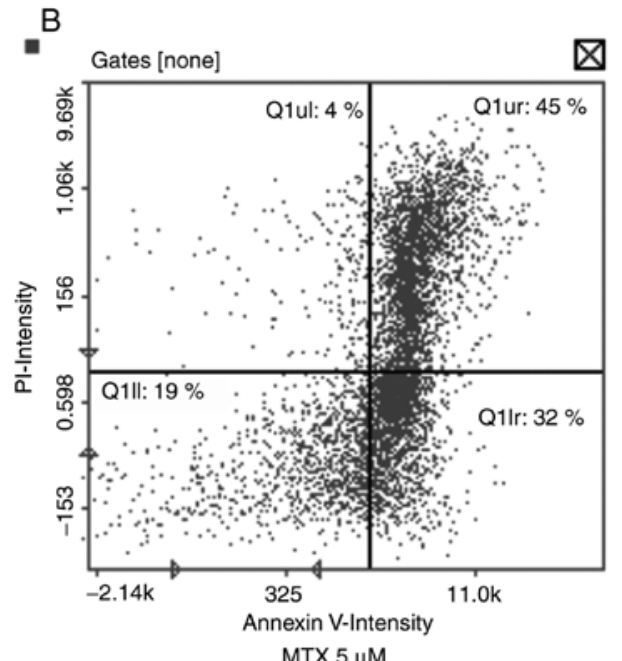

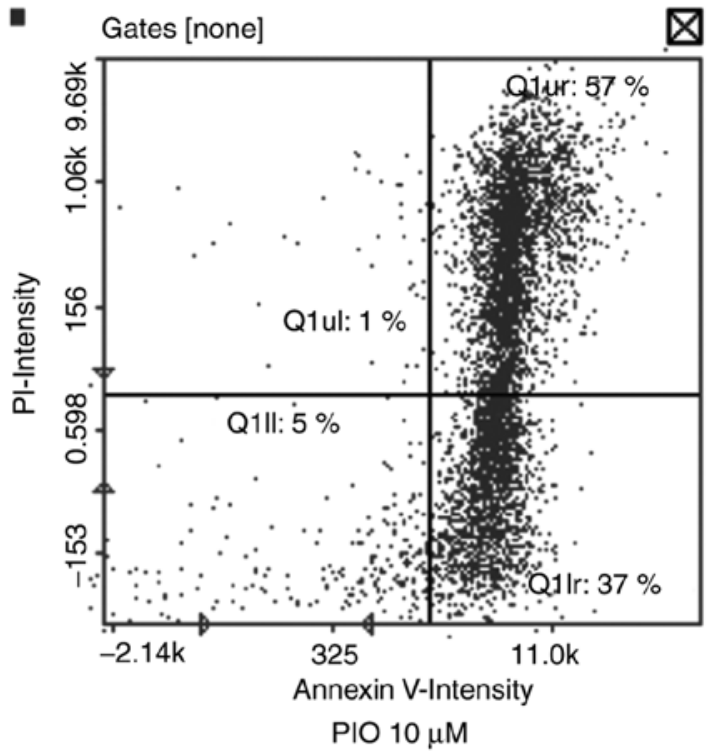

区

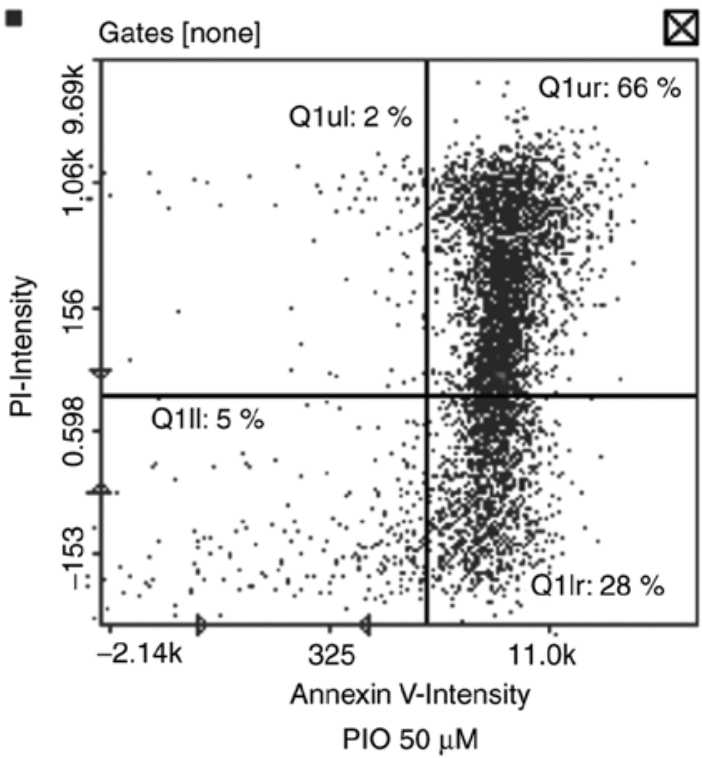

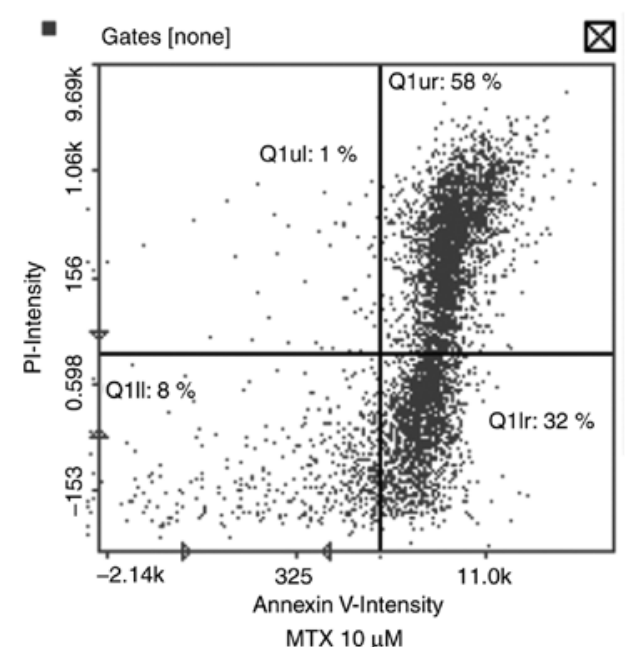

Figure 5. Percentage of viable, apoptotic and necrotic 769-P cells after a 24-h treatment with (A) pioglitazone (PIO) (B) methotrexate (MTX) or (C and D) their combination. Cells were stained with Hoechst 33342 in order to detect all the cells and with fluorescently labeled Annexin V (Annexin V-CF488A) and propidium iodide (PI) to distinguish apoptotic and necrotic cells. Early apoptotic cells exclude PI, while late-stage apoptotic and necrotic cells stain positively for both Annexin V and PI. Scatter plots demonstrate Annexin V-CF488A intensity vs. the intensity of PI. They are divided into four internal quadrants: left lower quadrant shows viable cells; right lower quadrants shows early apoptotic cells; right upper quadrants shows late apoptotic cells, and left upper quadrants shows necrotic cells. 

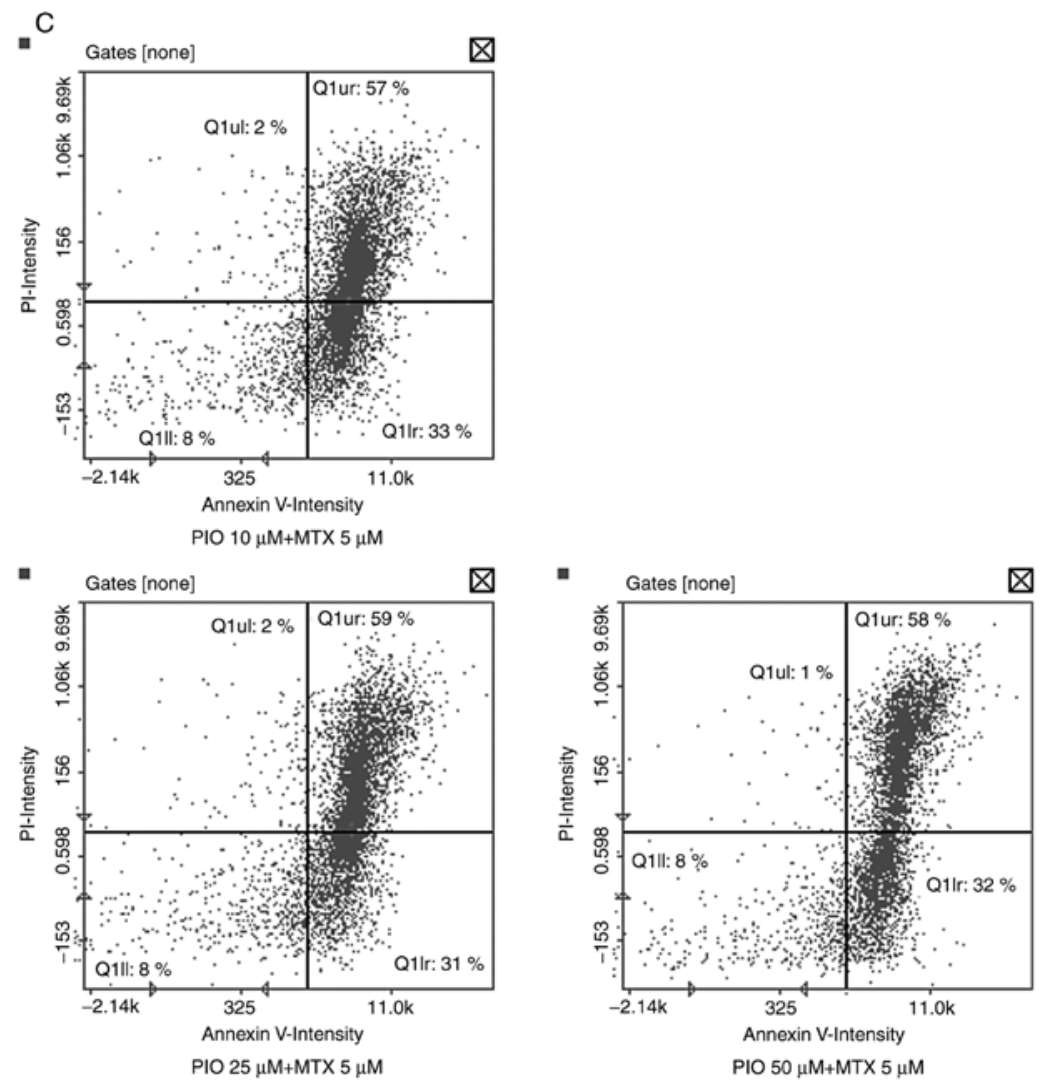

$\mathrm{D}$
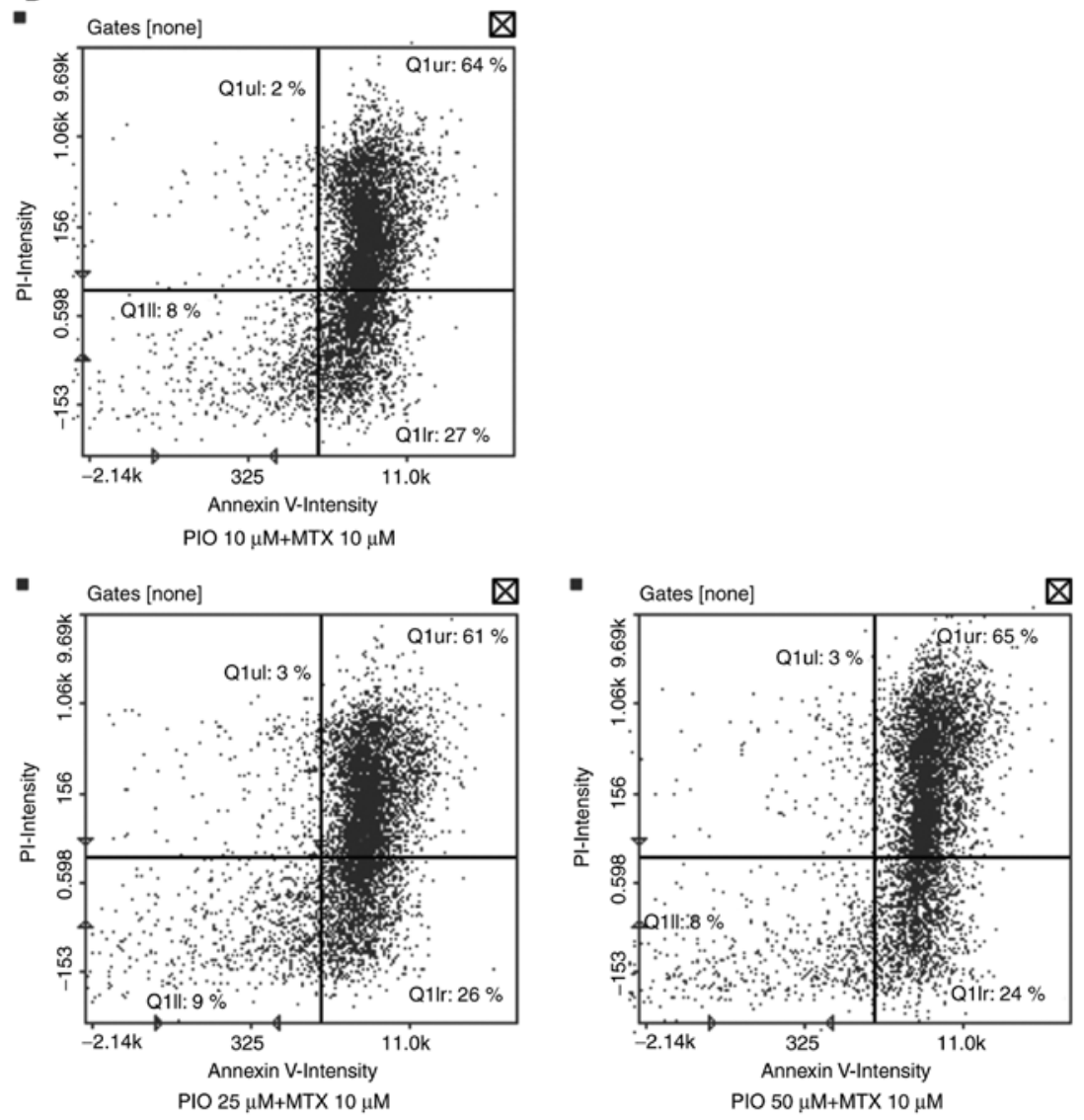

Figure 5. Continued. Percentage of viable, apoptotic and necrotic 769-P cells after a 24-h treatment with (A) pioglitazone (PIO) (B) methotrexate (MTX) or (C and D) their combination. Cells were stained with Hoechst 33342 in order to detect all the cells and with fluorescently labeled Annexin V (Annexin V-CF488A) and propidium iodide (PI) to distinguish apoptotic and necrotic cells. Early apoptotic cells exclude PI, while late-stage apoptotic and necrotic cells stain positively for both Annexin V and PI. Scatter plots demonstrate Annexin V-CF488A intensity vs. the intensity of PI. They are divided into four internal quadrants: left lower quadrant shows viable cells; right lower quadrants shows early apoptotic cells; right upper quadrants shows late apoptotic cells, and left upper quadrants shows necrotic cells. 
Table I. Effect of a 24-h treatment with PIO, MTX or their combinations on the percentage of viable, apoptotic and necrotic 769-P cells.

Percentage of cells

\begin{tabular}{|c|c|c|c|c|c|}
\hline \multirow[b]{2}{*}{ Treatment } & \multirow[b]{2}{*}{ Concentration $(\mu \mathrm{M})$} & & & & \\
\hline & & Viable & In early apoptosis & In late apoptosis & In necrosis \\
\hline Control & - & 81 & 4 & 6 & 9 \\
\hline \multirow[t]{3}{*}{ PIO } & 10 & 5 & 37 & 57 & 1 \\
\hline & $25 \mu \mathrm{M}$ & 5 & 35 & 59 & 1 \\
\hline & $50 \mu \mathrm{M}$ & 5 & 28 & 66 & 2 \\
\hline \multirow[t]{2}{*}{ MTX } & $5 \mu \mathrm{M}$ & 19 & 32 & 45 & 4 \\
\hline & $10 \mu \mathrm{M}$ & 8 & 32 & 58 & 1 \\
\hline \multirow[t]{3}{*}{$\mathrm{PIO}+\mathrm{MTX}$} & $10 \mu \mathrm{M}+5 \mu \mathrm{M}$ & 8 & 33 & 57 & 2 \\
\hline & $25 \mu \mathrm{M}+5 \mu \mathrm{M}$ & 8 & 31 & 59 & 2 \\
\hline & $50 \mu \mathrm{M}+5 \mu \mathrm{M}$ & 7 & 30 & 61 & 2 \\
\hline \multirow[t]{3}{*}{$\mathrm{PIO}+\mathrm{MTX}$} & $10 \mu \mathrm{M}+10 \mu \mathrm{M}$ & 8 & 27 & 64 & 2 \\
\hline & $25 \mu \mathrm{M}+10 \mu \mathrm{M}$ & 9 & 26 & 61 & 3 \\
\hline & $50 \mu \mathrm{M}+10 \mu \mathrm{M}$ & 8 & 24 & 65 & 3 \\
\hline
\end{tabular}

PIO, pioglitazone; MTX, methotrexate.

the percentages of late apoptotic 769-P cells treated with PIO or MTX were increased in a dose-dependent manner compared with that of the control cells (Table I and Fig. 5A and B). The early apoptotic death rate of 769-P cells treated with different concentrations of PIO or MTX was also enhanced but at a similar level, ranging from 28 to $37 \%$ compared with $4 \%$ in the control. The highest rate of late apoptotic cells (66\%) was achieved with the highest applied concentration of PIO after $24 \mathrm{~h}$ of treatment (Table I and Fig. 5A). Notably, after a 24-h incubation period with a combination of $\mathrm{PIO}(10,25$ and $50 \mu \mathrm{M})$ with MTX $(5 \mu \mathrm{M})$, the levels of apoptotic cells increased by $12-16 \%$ in comparison with those of cells treated with MTX only (Table I and Fig. 5C). PIO and MTX, either alone or in combination, did not increase the number of necrotic cells. The number of these cells ranged from 1 to $4 \%$ in comparison with $9 \%$ in the untreated group (Fig. 5A-D).

\section{Discussion}

Renal cell carcinoma ( $\mathrm{RCC}$ ) is the most common type of malignant renal tumor, and is mainly treated by surgery as chemotherapy and radiotherapy have limited effectiveness. The hypothesis that thiazolidinediones (TZDs), antidiabetic drugs and peroxisome proliferator-activated receptor $\gamma$ (PPAR $\gamma$ ) ligands could be considered in anticancer therapy is based on the following findings. PPAR $\gamma$ expression is high in numerous types of human malignant tumors including, RCC (27,45-49). In cancer cells, TZDs, through the genomic activation of PPAR $\gamma$, promote reduced migration, proliferation, inflammation and invasion, and upregulation of apoptosis (23). Therefore, evaluation of the anticancer potential of PPAR $\gamma$ agonists such as pioglitazone (PIO) is important. Previous in vitro studies have shown that $\mathrm{PIO}$ and rosiglitazone effectively limit cell differentiation, and induce cell cycle arrest and apoptosis in tumor cells $(35,49)$.

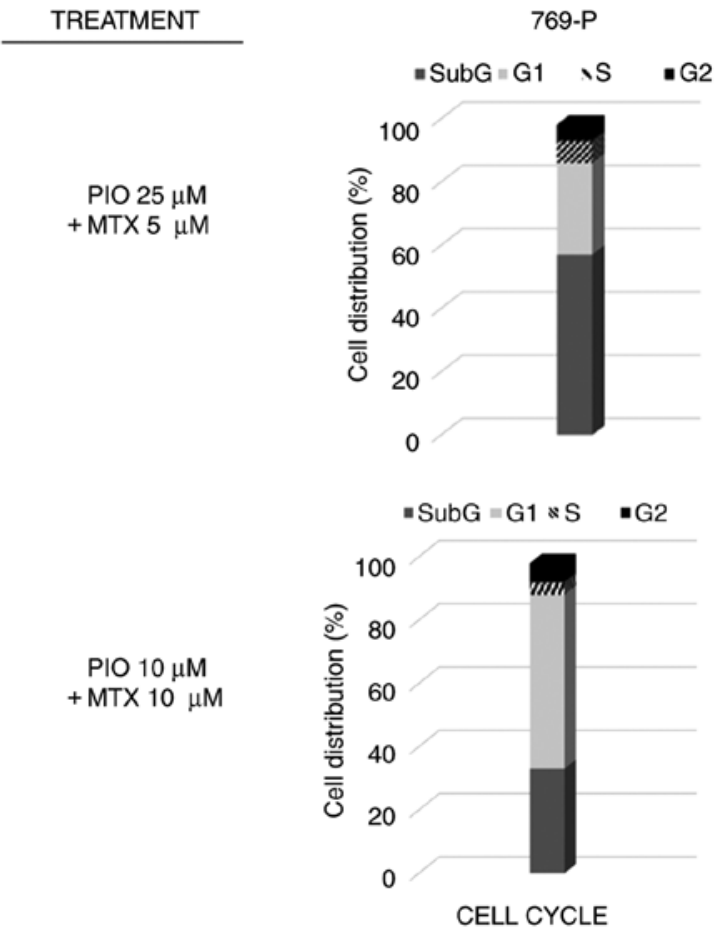

Figure 6. Cell cycle analysis of 769-P cells after a 24-h incubation with the most efficacious combinations of pioglitazone (PIO) and methotrexate (MTX) (upper image: PIO $25 \mu \mathrm{M}+\mathrm{MTX} 5 \mu \mathrm{M}$; lower image: PIO $10 \mu \mathrm{M}+\mathrm{MTX}$ $10 \mu \mathrm{M})$. The effect of combinations of PIO and MTX was investigated by an image analysis using the automated $\mathrm{NC}-3000^{\mathrm{TM}}$ system based on DAPI (4',6-diamidino-2-phenylindole) staining which allows the determination of the percentage division of cells in the different cell cycle phases (sub-G1/G1, $\mathrm{S}$ and $\mathrm{G} 2 / \mathrm{M}$ )

Each RCC study, including ours, has faced many different scientific issues, often limiting the means that could be used to provide more complex analysis. The first limitation of the 
present study is that the heterogeneity of RCC in vivo and the unique genomic profiles make it difficult to select the appropriate cancer cell lines in vitro and detect the expression of cell cycle and apoptosis-related genes by RT-qPCR and western blot analysis. This also has an impact on the number of assays that can be used for investigation of the apoptotic process. After long consideration, we decided to perform our study on only one cell line, 769-P, which was derived from primary human clear cell renal cell carcinoma (ccRCC), the most common (70-75\%) subtype of malignant kidney tumor. This cell line is most often used in RCC-focused research as 769-P cells have genomic resemblance with respect to human ccRCC [Cancer Genome Atlas (TCGA); Cancer Cell Line Encyclopedia (CCLE); COSMIC Cell Lines Project (CCLP)]. The cells produce high levels of VEGF and they have surface receptors which confirm the characteristic features of the ccRCC phenotype. The analysis in CCLE revealed that 769-P and CAL54 only have Tier 1 mutations in the key kidney genes included, making them the 'most reliable' in the sense of all their genomics alterations in key kidney cancer genes.

Our study showed that treatment with PIO $(10,25$ and $50 \mu \mathrm{M})$ significantly reduced the viability of the 769-P cells in a dose-dependent manner, while there was no significant effect on the normal Vero cell line, which was confirmed by microscopic evaluation. The application of PIO to the 769-P cell line resulted in a decrease in cell density and adverse changes in cell morphology. The most visible abnormalities were observed after administration of higher drug concentrations (25 and $50 \mu \mathrm{M})$; the cells were shrunk and had irregularly shape. This modification of cell morphology is probably due to the partial loss of mitochondrial membrane integrity, which is characteristic of the earliest phases of the apoptotic process. Although the mechanism of action still requires clarification, several reports indicate that the induction of cellular apoptosis by PPAR $\gamma$ agonists may be associated with changes in the mitochondrial membrane of cells, release of cytochrome $c$, and activation of proapoptotic proteins and caspases $(46,50,51)$. Yang et al (49) confirmed that TZDs markedly decreased Bcl-2 protein expression but increased the expression of the proapoptotic protein Bax in other renal adenocarcinoma cell lines (786-O and A498). Therefore, the present study assessed the effect of PIO on the induction of 769-P cell apoptosis. Our results confirmed the proapoptotic effect of PIO on 769-P cells, and showed that the percentage of apoptotic 769-P cells increased after a 24-h treatment with PIO. The number of the above cancer cells in the early phase of apoptosis increased by $24-33 \%$, and in the late phase by $51-60 \%$ in a dose-dependent manner in comparison with the numbers in untreated cancer cells. The result of apoptosis induction was consistent with the sub-G1 cell cycle arrest and decrease in G2-phase population observed in 769-P cells treated with PIO. Similar outcomes were described by Yang et al (49), who showed that PIO and troglitazone significantly inhibited the growth of the 786-O and A498 cell lines in a dose-dependent manner (5-50 $\mu \mathrm{M})$. In addition, PIO, as in our study, caused a dose-dependent increase in the sub-G1/G1 phases and effectively induced apoptosis in the above carcinoma cell lines. The study by Wang and Li (35) also confirmed the effectiveness of PIO. This PPAR $\gamma$ agonist inhibited the growth of the human lung cancer cell lines A549 and H1299, by cell cycle arrest in sub-G1/G1 phase. The above observations are also consistent with our results. Similarly, Rumi et al (52) showed a marked inhibition of growth of the esophageal cancer cell line SCC by PPAR $\gamma$ agonists, which was associated with sub-G1/G1 cell cycle arrest.

The issue concerning the resistance of cancer cells to antifolates, which is widely discussed in the scientific literature, was also revealed in our study $(33,36)$. Treatment of cancer cells with methotrexate (MTX) (5 and $10 \mu \mathrm{M})$ for $24 \mathrm{~h}$ did not significantly affect their morphology or viability, as evaluated by MTT assay and microscopic analysis, respectively. It is also worth mentioning that ccRCC, represented by the 769-P cell line, has a more complex genetic profile than other kidney cancers which may translate into difficulties in interpreting the research results. The cell cycle assay also showed accumulation of cells in the sub-G1 phase with a simultaneous decrease in the number of cells in the G2 phase, particularly after applying high concentrations of MTX. It should be highlighted that cell cycle arrest may proceed to apoptotic cell death. In the present study, MTX-induced apoptosis of 769-P cells was also noted. Our studies confirmed the hypothesis that antidiabetic drugs can increase the efficacy of the treatment of different types of cancer by increasing the sensitivity of tumor cells to certain chemotherapeutic agents. The specific combination therapy of PIO and MTX probably increased the sensitivity of 769-P cells to MTX. The viability of cancer cells significantly decreased by $40 \%$ after a 24 -h treatment following combination treatment using both drugs. It is worth noting that a higher dose of $\operatorname{MTX}(10 \mu \mathrm{M})$ in combination therapy with various concentrations of PIO did not increase the level of cytotoxicity against 769-P cells in comparison with that exhibited by cancer cells treated with a lower dose of MTX. The effects for both doses were comparable. Thus, it may be concluded that there is no need to increase the MTX doses. There are no beneficial effects on the growth inhibition of cancer cells, but the risk of cytotoxicity towards normal cells is much higher. Our study showed that the decrease in Vero cell viability after combination therapy was comparable with that exhibited by cells treated with MTX alone, and PIO has no impact on this. This is an important observation due to the risk of nephrotoxicity, which is one of the most dangerous complications of MTX treatment, and is usually associated with higher doses of this cytostatic agent administered to patients. The most beneficial in the clinical setting appears to be the combination of low doses of PIO $(10 \mu \mathrm{M})$ and MTX $(5 \mu \mathrm{M})$, based on the effects of growth inhibition of cancer cells and the low risk of cytotoxicity towards normal cells. In the future, we intend to expand our research to other renal cancer lines in order to verify the findings of this study. In addition, newly selected RCC cell line-focused experiments should also enable us to investigate apoptosis through various techniques such as western blot analysis or Caspase Glo analysis.

In summary, the present study provides evidence that antidiabetic drugs acting as PPAR $\gamma$ agonists such as PIO may have a significant impact on the treatment not only of diabetes but also progression of kidney cancer. Unravelling the mechanisms responsible for the resistance of renal cell adenocarcinoma to MTX will facilitate the development of new effective therapies. Our research demonstrated that certain combinations of 
PIO with MTX inhibited the proliferation of 769-P cells more effectively than MTX or PIO alone. A combination of PIO $(25 \mu \mathrm{M})$ and MTX $(5 \mu \mathrm{M})$ had the strongest effect on cancer cells, which was confirmed by both cell cycle as well as apoptosis analyses. In addition, this particular drug combination proved to be safe for normal Vero cells. The results obtained clearly indicate the advantageous effects of PIO and MTX combination therapy; therefore, it may be an innovative and effective method for the treatment of renal cancer in the future.

\section{Acknowledgements}

Not applicable.

\section{Funding}

The present study was supported by Funds for Statutory Activity of Medical University of Lublin, Poland (grant no. DS38/2018).

\section{Availability of data and materials}

All data generated and/or analyzed during this study are included in this published article.

\section{Authors' contributions}

IPC and MGG designed and directed the experiments and wrote the manuscript. IPC, MGG and MS performed the in vitro study. DNC and $\mathrm{MH}$ collected and analyzed the data. $\mathrm{MH}$ and MS performed the statistical analysis. DNC and $\mathrm{MH}$ interpreted the results of statistical analysis. $\mathrm{MH}$ was involved in drafting the manuscript and revised critically the final version of the manuscript. MI performed the cell cycle assay, cell apoptosis analysis and microscopic analysis and collected the data and done graphic presentation of the results. $\mathrm{AK}$ and JD were involved in the conception of the study and revised critically the final version of the manuscript. AK supervised cell cycle and cell apoptosis analysis. JD supervised the in vitro cytotoxicity study. All authors read and approved the final version of manuscript.

\section{Ethics approval and consent to participate}

Not applicable.

\section{Patient consent for publication}

Not applicable.

\section{Competing interests}

The authors declare that they have no competing interests.

\section{References}

1. Siegel RL, Miller KD and Jemal A: Cancer statistics, 2018. CA Cancer J Clin 68: 7-30, 2018.

2. Torre LA, Siegel RL, Ward EM and Jemal A: Global cancer incidence and mortality rates and trends-an update. Cancer Epidemiol Biomarkers Prev 25: 16-27, 2016.
3. Al-Dimassi S, Abou-Antoun T and El-Sibai M: Cancer cell resistance mechanisms: A mini review. Clin Transl Oncol 16: 511-516, 2014.

4. Hanahan D and Weinberg RA: Hallmarks of cancer: The next generation. Cell 144: 646-674, 2011.

5. Ljungberg B, Campbell SC, Choi HY, Jacqmin D, Lee JE, Weikert S and Kiemeney LA: The epidemiology of renal cell carcinoma. Eur Urol 60: 615-621, 2011.

6. Cancer Research UK: Kidney cancer statistics: https://www. cancerresearchuk.org/health-professional/cancer-statistics/statisticsby-cancer-type/kidney-cancer/incidence-heading-Zero. Accessed April 13, 2019.

7. Lipworth L, Tarone RE, Lund L and McLaughlin JK: Epidemiologic characteristics and risk factors for renal cell cancer. Clin Epidemiol 1: 33-43, 2009.

8. Capitanio U, Bensalah K, Bex A, Boorjian SA, Bray F, Coleman J, Gore JL, Sun M, Wood C and Russo P: Epidemiology of renal cell carcinoma. Eur Urol 75: 74-84, 2019.

9. Mathew A, Devesa SS, Fraumeni JF Jr and Chow WH: Global increases in kidney cancer incidence, 1973-1992. Eur J Cancer Prev 11: 171-178, 2002.

10. Habib SL, Prihoda TJ, Luna M and Werner SA: Diabetes and risk of renal cell carcinoma. J Cancer 3: 42-48, 2012.

11. Shi Y and Hu FB: The global implications of diabetes and cancer. Lancet 383: 1947-1948, 2014.

12. Song XS, Fan B, Ma C, Yu ZL, Bai SS, Zhang Z, Zhao H, Zhu XQ, $\mathrm{He}$ SL, Chen F, et al: Clinical research on the correlations between type 2 diabetes mellitus and renal clear cell carcinoma. Zhonghua Wai Ke Za Zhi 51: 627-630, 2013 (In Chinese).

13. Hou Y, Zhou M, Xie J, Chao P, Feng Q and Wu J: High glucose levels promote the proliferation of breast cancer cells through GTPases. Breast Cancer (Dove Med Press) 9: 429-436, 2017.

14. Giovannucci E, Harlan DM, Archer MC, Bergenstal RM, Gapstur SM, Habel LA, Pollak M, Regensteiner JG and Yee D: Diabetes and cancer: A consensus report. Diabetes Care 33: 1674-1685, 2010.

15. Psutka SP, Stewart SB, Boorjian SA, Lohse CM, Tollefson MK, Cheville JC, Leibovich BC and Thompson RH: Diabetes mellitus is independently associated with an increased risk of mortality in patients with clear cell renal cell carcinoma. J Urol 192: 1620-1627, 2014.

16. Sen S, He Y, Koya D and Kanasaki K: Cancer biology in diabetes. J Diabetes Investig 5: 251-264, 2014.

17. Pearson-Stuttard J, Zhou B, Kontis V, Bentham J, Gunter MJ and Ezzati M: Worldwide burden of cancer attributable to diabetes and high body-mass index: A comparative risk assessment. Lancet Diabetes Endocrinol 6: 95-104, 2018.

18. Kasznicki J, Sliwinska A and Drzewoski J: Metformin in cancer prevention and therapy. Ann Transl Med 2: 57, 2014.

19. Zhu C, Wei J, Tian X, Li Y and Li X: Prognostic role of PPAR- $\gamma$ and PTEN in the renal cell carcinoma. Int J Clin Exp Pathol 8: 12668-12677, 2015.

20. Liu J, Li M, Song B, Jia C, Zhang L, Bai X and Hu W: Metformin inhibits renal cell carcinoma in vitro and in vivo xenograft. Urol Oncol 31: 264-270, 2013.

21. Yuan J, Takahashi A, Masumori N, Uchida K, Hisasue S, Kitamura $\mathrm{H}$, Itoh $\mathrm{N}$ and Tsukamoto T: Ligands for peroxisome proliferator-activated receptor gamma have potent antitumor effect against human renal cell carcinoma. Urology 65: 594-599, 2005.

22. Grygiel-Górniak B: Peroxisome proliferator-activated receptors and their ligands: Nutritional and clinical implications-a review. Nutr J 13: 17-25, 2014.

23. Fröhlich E and Wahl R: Chemotherapy and chemoprevention by thiazolidinediones. BioMed Res Int 2015: 845340, 2015.

24. Zhang GY, Ahmed N, Riley C, Oliva K, Barker G, Quinn MA and Rice GE: Enhanced expression of peroxisome proliferator-activated receptor gamma in epithelial ovarian carcinoma. Br J Cancer 92: 113-119, 2005.

25. Inoue K, Kawahito Y, Tsubouchi Y, Kohno M, Yoshimura R, Yoshikawa T and Sano H: Expression of peroxisome proliferator-activated receptor gamma in renal cell carcinoma and growth inhibition by its agonists. Biochem Biophys Res Commun 287: 727-732, 2001

26. Bull AW: The role of peroxisome proliferator-activated receptor gamma in colon cancer and inflammatory bowel disease. Arch Pathol Lab Med 127: 1121-1123, 2003.

27. Smith MR and Kantoff PW: Peroxisome proliferator-activated receptor gamma (PPAR gamma) as a novel target for prostate cancer. Invest New Drugs 20: 195-200, 2002. 
28. Mansure JJ, Nassim R, Chevalier S, Szymanski K, Rocha J, Aldousari $\mathrm{S}$ and Kassouf W: A novel mechanism of PPAR gamma induction via EGFR signalling constitutes rational for combination therapy in bladder cancer. PLoS One 8: e55997, 2013.

29. Lakshmi SP, Reddy AT, Banno A and Reddy RC: PPAR agonists for the prevention and treatment of lung cancer. PPAR Res 2017: 8252796, 2017.

30. Sarafidis PA and Bakris GL: Protection of the kidney by thiazolidinediones: An assessment from bench to bedside. Kidney Int 70: 1223-1233, 2006.

31. Sarafidis PA, Georgianos PI and Lasaridis AN: PPAR- $\gamma$ agonism for cardiovascular and renal protection. Cardiovasc Ther 29: 377-384, 2011.

32. Hagner $\mathrm{N}$ and Joerger M: Cancer chemotherapy: Targeting folic acid synthesis. Cancer Manag Res 2: 293-301, 2010.

33. Gonen $\mathrm{N}$ and Assaraf YG: Antifolates in cancer therapy: Structure, activity and mechanisms of drug resistance. Drug Resist Updat 15: 183-210, 2012.

34. Morales C, Ribas M, Aiza G and Peinado MA: Genetic determinants of methotrexate responsiveness and resistance in colon cancer cells. Oncogene 24: 6842-6847, 2005

35. Wang $\mathrm{J}$ and Li G: Mechanisms of methotrexate resistance in osteosarcoma cell lines and strategies for overcoming this resistance. Oncol Lett 9: 940-944, 2015.

36. Bertino JR, Göker E, Gorlick R, Li WW and Banerjee D: Resistance mechanisms to methotrexate in tumors. Oncologist 1: 223-226, 1996.

37. Assaraf YG: Molecular basis of antifolate resistance. Cancer Metastasis Rev 26: 153-181, 2007.

38. Chen ZS, Lee K, Walther S, Raftogianis RB, Kuwano M, Zeng H and Kruh GD: Analysis of methotrexate and folate transport by multidrug resistance protein 4 (ABCC4): MRP4 is a component of the methotrexate efflux system. Cancer Res 62: 3144-3150, 2002.

39. Sirotnak FM, Wendel HG, Bornmann WG, Tong WP, Miller VA, Scher HI and Kris MG: Co-administration of probenecid, an inhibitor of a cMOAT/MRP-like plasma membrane ATPase, greatly enhanced the efficacy of a new 10-deazaaminopterin against human solid tumors in vivo. Clin Cancer Res 6: 3705-3712, 2000.

40. Ichioka D, Miyazaki J, Inoue T, Kageyama S, Sugimoto M, Mitsuzuka K, Matsui Y, Shiraishi Y,Kinoshita H, Wakeda H, et al Impact of renal function of patients with advanced urothelial cancer on eligibility for first-line chemotherapy and treatment outcomes. Jpn J Clin Oncol 45: 867-873, 2015.

41. Koga H, Selvendiran K, Sivakumar R, Yoshida T, Torimura T, Ueno $\mathrm{T}$ and Sata M: PPAR $\gamma$ potentiates anticancer effects of gemcitabine on human pancreatic cancer cells. Int J Oncol 40 679-685, 2012
42. Ling S, Feng T, Ke Q, Fan N, Li L, Li Z, Dong C, Wang C, Xu F, Li Y and Wang L: Metformin inhibits proliferation and enhances chemosensitivity of intrahepatic cholangiocarcinoma cell lines. Oncol Rep 31: 2611-2618, 2014.

43. Mahmoud MF and El Shazly SM: Pioglitazone protects against cisplatin induced nephrotoxicity in rats and potentiates its anticancer activity against human renal adenocarcinoma cell lines. Food Chem Toxicol 51: 114-122, 2013.

44. Wlodkowic D, Telford W, Skommer J and Darzynkiewicz Z: Apoptosis and beyond: Cytometry in studies of programmed cell death. Methods Cell Biol 103: 55-98, 2011.

45. Guan YF, Zhang YH, Breyer RM, Davis L and Breyer MD: Expression of peroxisome proliferator-activated receptor gamma (PPAR gamma) in human transitional bladder cancer and its role in inducing cell death. Neoplasia 1: 330-339, 1999.

46. Hashimoto Y, Shimada Y, Itami A, Ito T, Kawamura J, Kawabe A, Kaganoi J, Maeda M, Watanabe G and Imamura M: Growth inhibition through activation of peroxisome proliferatoractivated receptor gamma in human oesophageal squamous cell carcinoma. Eur J Cancer 39: 2239-2246, 2003.

47. Mössner R, Schulz U, Krüger U, Middel P, Schinner S, Füzesi L, Neumann C and Reich K: Agonists of peroxisome proliferator-activated receptor gamma inhibit cell growth in malignant melanoma. J Invest Dermatol 119: 576-582, 2002.

48. Youssef J and Badr M: Peroxisome proliferator-activated receptors and cancer: Challenges and opportunities. $\mathrm{Br} \mathrm{J}$ Pharmacol 164: 68-82, 2011.

49. Yang FG, Zhang ZW, Xin DQ, Shi CJ, Wu JP, Guo YL and Guan YF: Peroxisome proliferator-activated receptor $\gamma$ ligands induce cell cycle arrest and apoptosis in human renal carcinoma cell lines. Acta Pharmacol Sin 26: 753-761, 2005.

50. Elrod HA and Sun SY: PPAR gamma and apoptosis in cancer. PPAR Res 2008: 704165, 2008.

51. Bonofiglio D, Cione E, Qi H, Pingitore A, Perri M, Catalano S, Vizza D, Panno ML, Genchi G, Fuqua SA and Andò S: Combined low doses of PPAR gamma and RXR ligands trigger an intrinsic apoptotic pathway in human breast cancer cells. Am J Pathol 175: 1270-1280, 2009.

52. Rumi MA, Sato H, Ishihara S, Ortega C, Kadowaki Y and Kinoshita Y: Growth inhibition of esophageal squamous carcinoma cells by peroxisome proliferator-activated receptor- $\gamma$ ligands. J Lab Clin Med 140: 17-26, 2002. 